\title{
Quantitative Analysis of Metal Contents in Korean Herbs and Herbal Products to Give Advice for Metal Allergic Patient
}

\author{
Min Jung Choi, Ji Yeon Byun, Hae Young Choi, You Won Choi \\ Department of Dermatology, Ewha Womans University College of Medicine, Seoul, Korea
}

Background: Herbs have been used worldwide as complementary and alternative medicines. In Korea, herbs for medical purpose are strictly controlled by the Korea Food and Drug Administration (KFDA). But it does not provide standards for metal antigens. Objective: This study conducted to identify the metal contents of Korean herbs and herbal products and to give information on counselling metal allergic patient. Methods: The concentration of three metal allergens with high antigenicity, cobalt (Co), chromium ( $\mathrm{Cr}$ ), nickel (Ni) was quantitatively determined using inductively coupled plasma with a mass spectrometer after nitric acid $\left(\mathrm{HNO}_{3}\right)$ digestion. The herbal objects are as follows: 1$)$ ten kinds of herb plants, 2) ten herbal products sold in Korean drugstores, and 3) ten herbal extracts prescribed by Korean herbal doctors. Results: In 30 samples, $\mathrm{Ni}$ and $\mathrm{Cr}$ were detected in all items. Co was not detected in two drugstore products. Conclusion: Although the levels of metal detected in this study were very low relative to international guidelines and KFDA regulations, the herbal preparations contained similar or higher metal levels than known metal-rich foods. It can cause problems when it added to the daily diet and cause deterioration of skin lesions of metal sensitized

Received September 21, 2018, Revised February 13, 2019, Accepted for publication February 25, 2019

Corresponding author: You Won Choi, Department of Dermatology, Ewha Womans University Mokdong Hospital, 1071 Anyangcheon-ro, Yangcheon-gu, Seoul 07985, Korea. Tel: 82-2-2650-5159, Fax: 82-2-2652-6925, E-mail: uwon313@ewha.ac.kr ORCID: https://orcid.org/0000-0001-6315-3889

This is an Open Access article distributed under the terms of the Creative Commons Attribution Non-Commercial License (http://creativecommons. org/licenses/by-nc/4.0) which permits unrestricted non-commercial use, distribution, and reproduction in any medium, provided the original work is properly cited.

Copyright (c) The Korean Dermatological Association and The Korean Society for Investigative Dermatology person. (Ann Dermatol 31(4) $414 \sim 419,2019$ )

\section{-Keywords-}

Complementary therapies, Dermatitis, contact, Herbal medicine, Metals

\section{INTRODUCTION}

Herbs have been used worldwide as complementary and alternative medicines (CAMs) for thousands of years. Korea has traditionally used a variety of herbal products, and $85.5 \%$ of the Korean general population has used an herbal medicine more than once in their lifetime ${ }^{1}$. Herbs are cultivated and harvested in natural environments and, thus, are heavily influenced by metal contamination of the soil and surrounding environment. Therefore, many countries consistently analyze the metal contents of herbs and herbal products ${ }^{2-5}$.

In Korea, herbs are categorized as 'food ingredients' when used as foodstuffs and 'herbal plants' when used for medicinal purposes. Herbal plants used by Korean herbal doctors, the Hospital of Oriental Medicine, pharmaceutical companies, pharmacies, and Oriental medicine dispensaries should meet quality-control standards based on the regulations of the Korea Food and Drug Administration (KFDA) ${ }^{6-9}$. However, the updated Korean herb and herbal-product purity guidelines include only four heavy metals, arsenic (As), lead (Pd), cadmium (Cd), and mercury $(\mathrm{Hg})$, whereas other metals are measured as the sum of the total metals using the sulfide precipitation method. In Korea, $43.6 \%$ of adverse reactions associated with Oriental medicines involve dermatological problems, which are the most common side effects ${ }^{1}$. For example, contact der- 
matitis, arsenic keratosis, phototoxicity, and alopecia have been reported after using herbal products ${ }^{10}$. Since the 2000s, countries around the world have noted that CAMs, including herbs, may be an important ingestion factor for metal antigens such as nickel, chromium, cobalt, and mercury $^{11-14}$. However, no studies have investigated the metal contents of Korean herbs and herbal products with the potential to cause contact dermatitis. Therefore, this study aimed to identify the metal contents of Korean herbs and herbal products and to give information on counselling metal allergic patient compared with previous reports in literature reviews.

\section{MATERIALS AND METHODS}

\section{Study materials}

In this study, 10 herbal plants that are ranked among the top 10 most commonly used in Korea according to the 2010 Korea National Statistical Office Notice were obtained from a KFDA approved pharmaceutical company. Ten herbal products sold in Korean drugstores and 10 herbal extracts prescribed by Korean herbal doctors were purchased randomly.

\section{Study methods}

After all solid samples were ground homogeneously, $0.5 \mathrm{~g}$ of sample was placed in Teflon container and mixed with $7 \mathrm{ml}$ undiluted nitric acid $\left(\mathrm{HNO}_{3}\right)$. The mixture heated to $150^{\circ} \mathrm{C}$ and cooled to room temperature. After opening lid, the mixture was reheated to achieve a dry state. Next, $5 \mathrm{ml}$ undiluted $\mathrm{HNO}_{3}$ and $1 \mathrm{ml}$ perchloric acid were added to the dry material and sealed. The mixture was thermally decomposed at $150^{\circ} \mathrm{C}$, cooled to room temperature, reheated until it had dried, and then diluted with $1 \% \mathrm{HNO}_{3}$ to produce a total $50 \mathrm{ml}$.

For liquid samples, $1 \mathrm{ml}$ of the liquid sample was placed in $60 \mathrm{ml}$ Teflon container and mixed with $2 \mathrm{ml}$ undiluted $\mathrm{HNO}_{3}$. The mixture heated to $150^{\circ} \mathrm{C}$ and cooled to room temperature. After opening lid, the mixture was reheated to achieve a dry state and diluted with $1 \% \mathrm{HNO}_{3}$ to produce a total $50 \mathrm{ml}$.

The preprocessed samples were analyzed twice to measure the three metals: $\mathrm{Cr}, \mathrm{Ni}$ and $\mathrm{Co}$ which could cause allergic contact dermatitis listed in Fisher's contact dermatitis 6 th edition ${ }^{15}$. An inductively coupled plasma mass spectrometer (iCAP ${ }^{\mathrm{TM}}$ TQ ICP-MS ${ }^{\mathbb{R}}$; Thermo Scientific, Bremen, Germany) was used to assess the herbal plants and herbal products sold in drugstores, whereas a different inductively coupled plasma mass spectrometer (X-SERIES ICP-MS ${ }^{\circledR}$; Thermo Elemental, Winsford, UK) was used to assess the herbal extracts.
The analytical detection limits for the iCAP ${ }^{\mathrm{TM}}$ TQ ICP-MS ${ }^{\circledR}$ were as follows: $0.001 \mu \mathrm{g} / \mathrm{kg}$ for $\mathrm{Cr}, 0.001 \mu \mathrm{g} / \mathrm{kg}$ for $\mathrm{Ni}$, $0.001 \mu \mathrm{g} / \mathrm{kg}$ for Co. The analytical detection limits for the X-SERIES ICP-MS ${ }^{\circledR}$ were $0.1 \mu \mathrm{g} / \mathrm{kg}$ for $\mathrm{Cr}, 0.2 \mu \mathrm{g} / \mathrm{kg}$ for $\mathrm{Ni}$ and $0.1 \mu \mathrm{g} / \mathrm{kg}$ for Co.

\section{Calculation of mean daily metal intake}

To calculate the mean daily metal intakes from herbal plants and herbal extracts, either the daily intake doses that were described on the medicine packages or the daily intake directions described by Korean herbal doctors or pharmacists were used. The daily intake doses for herbal plants were calculated according to the mean daily intake doses suggested by the KFDA for evaluating hazards associated with herbal medicines in 2016 (Table 1) ${ }^{16}$. The KFDA study conducted for 174 kind of herbal material in total of 5,000 Korean distribution channels which trading herbs (oriental medicine, oriental medicine hospitals, oriental pharmacies, pharmacies and herbal medicine pharmacies) for 2 years. Total 62,741 herbal prescription and herbal item usage amount information had been collected by survey paper response or visiting survey ${ }^{16}$.

\section{RESULTS}

The results from the quantitative analyses of 30 herbal items, including herbal plants, herbal products, and herbal extracts, are shown in Table 2.

\section{Analytical results according to metal type}

$\mathrm{Ni}$ was detected in all 30 items. The mean $\mathrm{Ni}$ content was $0.736 \mathrm{ppm}(0.002 \sim 2.224 \mathrm{ppm})$ in herbal plants, $0.392 \mathrm{ppm}$ $(0.011 \sim 0.958 \mathrm{ppm})$ in herbal products sold in Korean drugstores, and $0.140 \mathrm{ppm}(0.085 \sim 0.214 \mathrm{ppm})$ in herbal extracts. Thus, the mean daily $\mathrm{Ni}$ intake was $5.048 \mu \mathrm{g} / \mathrm{d}$ $(0.011 \sim 14.275 \mu \mathrm{g} / \mathrm{d})$ from herbal plants, $8.409 \mu \mathrm{g} / \mathrm{d}$

Table 1. Mean daily intake dose of Korean herbs ${ }^{16}$

\begin{tabular}{rlc}
\hline Order & \multicolumn{1}{c}{ Items } & $\begin{array}{c}\text { Mean daily } \\
\text { intake dose }(\mathrm{g})\end{array}$ \\
\hline 1 & Herb A (Angelica Gigas root) & 6.42 \\
2 & Herb B (Poria) & 6.84 \\
3 & Herb C (Astragalus root) & 7.53 \\
4 & Herb D (Peony root) & 6.29 \\
5 & Herb E (Licorice) & 5.42 \\
6 & Herb F (Cnidium rhizome) & 6.41 \\
7 & Herb G (Prepared Rehmannia root) & 8.27 \\
8 & Herb H (Liriope tuber) & 6.8 \\
9 & Herb I (Alisma rhizome) & 7.3 \\
10 & Herb J (Bupleurum root) & 6.3 \\
\hline
\end{tabular}


Table 2. Metal content in Korean herbs, herbal products and herbal extracts

\begin{tabular}{|c|c|c|c|c|c|c|c|}
\hline & \multirow{2}{*}{ Items } & \multicolumn{3}{|c|}{ Metal content (ppm) } & \multicolumn{3}{|c|}{ Daily metal intake $(\mu \mathrm{g})$} \\
\hline & & $\mathrm{Cr}$ & Co & $\mathrm{Ni}$ & $\mathrm{Cr}$ & Co & $\mathrm{Ni}$ \\
\hline \multirow[t]{10}{*}{ I. Material (solid) } & Herb A (Angelica Gigas root) & 1.582 & 0.413 & 2.224 & 10.155 & 2.654 & 14.275 \\
\hline & Herb B (Poria) & 0.020 & 0.052 & 0.002 & 0.136 & 0.352 & 0.011 \\
\hline & Herb C (Astragalus root) & 2.234 & 0.059 & 1.308 & 16.822 & 0.448 & 9.850 \\
\hline & Herb D (Peony root) & 1.351 & 0.052 & 0.760 & 8.496 & 0.324 & 4.783 \\
\hline & Herb E (Licorice) & 0.522 & 0.058 & 0.334 & 2.832 & 0.315 & 1.812 \\
\hline & Herb F (Cnidium rhizome) & 0.366 & 0.091 & 0.253 & 2.349 & 0.582 & 1.621 \\
\hline & Herb G (Prepared Rehmannia root) & 3.685 & 0.331 & 1.021 & 30.478 & 2.739 & 8.447 \\
\hline & Herb H (Liriope tuber) & 2.959 & 0.078 & 0.409 & 20.118 & 0.531 & 2.780 \\
\hline & Herb I (Alisma rhizome) & 0.485 & 0.090 & 0.309 & 3.543 & 0.657 & 2.255 \\
\hline & Herb J (Bupleurum root) & 2.225 & 0.174 & 0.738 & 14.019 & 1.094 & 4.648 \\
\hline \multirow[t]{6}{*}{ II. Final product (solid) } & Herbal product F (Danggwisusan Extract Granules) & 0.270 & 0.069 & 0.502 & 2.431 & 0.620 & 4.516 \\
\hline & Herbal product G (Socheongryongtang Mix Extract Powder) & 0.360 & 0.114 & 0.468 & 3.242 & 1.024 & 4.215 \\
\hline & Herbal product H (Eungyosan Extract Granules) & 0.462 & 0.082 & 0.958 & 4.157 & 0.738 & 8.620 \\
\hline & Herbal product I (Banhasasimtang Mix Extract Powder) & 0.239 & 0.091 & 0.437 & 2.150 & 0.823 & 3.932 \\
\hline & Herbal product J (Insampaedogsan Mix Extract Powder) & 0.996 & 0.066 & 0.652 & 8.963 & 0.593 & 5.865 \\
\hline & Herbal product E (Jeongrohwan Pill) & 0.547 & 0.120 & 0.658 & 0.984 & 0.215 & 1.184 \\
\hline \multirow[t]{4}{*}{ III. Final product (liquid) } & Herbal product A (Ssanghwatang Extract Solutions) & 0.003 & 0.015 & 0.074 & 0.860 & 4.430 & 22.166 \\
\hline & Herbal product B (Gaswhalmyungsu Solution) & 0.041 & Bdl & 0.011 & 9.113 & NE & 2.377 \\
\hline & Herbal product C (Hyanggaltang Extract Solutions) & 0.020 & 0.012 & 0.076 & 6.105 & 3.674 & 22.822 \\
\hline & $\begin{array}{l}\text { Herbal product D (Uhwangcheongsimwon Solution } \\
\text { [Altered Prescription]) }\end{array}$ & 0.113 & Bdl & 0.084 & 11.268 & NE & 8.394 \\
\hline \multirow[t]{10}{*}{ IV. Herbal extract (liquid) } & Herbal extract $A$ & 0.002 & 0.016 & 0.130 & 0.728 & 4.724 & 39.024 \\
\hline & Herbal extract B & 0.009 & 0.013 & 0.214 & 2.695 & 4.028 & 64.296 \\
\hline & Herbal extract $\mathrm{C}$ & 0.005 & 0.009 & 0.103 & 1.390 & 2.818 & 30.960 \\
\hline & Herbal extract D & 0.009 & 0.015 & 0.145 & 2.766 & 4.418 & 43.524 \\
\hline & Herbal extract E & 0.007 & 0.018 & 0.159 & 1.981 & 5.308 & 47.616 \\
\hline & Herbal extract $F$ & 0.007 & 0.020 & 0.154 & 2.153 & 6.005 & 46.164 \\
\hline & Herbal extract $G$ & 0.008 & 0.024 & 0.139 & 2.480 & 7.130 & 41.604 \\
\hline & Herbal extract $\mathrm{H}$ & 0.007 & 0.021 & 0.141 & 2.154 & 6.191 & 42.324 \\
\hline & Herbal extract I & 0.005 & 0.011 & 0.085 & 1.463 & 3.258 & 25.416 \\
\hline & Herbal extract J & 0.008 & 0.020 & 0.131 & 2.383 & 6.101 & 39.192 \\
\hline
\end{tabular}

Bdl: below detection limit, NE: not estimated.

$(1.184 \sim 22.822 \mu \mathrm{g} / \mathrm{d})$ from herbal products sold in Korean drugstores, and $42.012 \mu \mathrm{g} / \mathrm{d}(25.416 \sim 64.296 \mu \mathrm{g} / \mathrm{d})$ from herbal extracts. Of the 10 herbal extracts, 1 in particular (Herbal extract B) had a mean daily Ni intake of $64.296 \mu \mathrm{g} / \mathrm{d}$, and 6 had a daily mean intake greater than $40 \mu \mathrm{g} / \mathrm{d}$.

$\mathrm{Cr}$ was detected in all 30 samples. The mean $\mathrm{Cr}$ content was 1.543 ppm (0.020 3.685 ppm) in herbal plants, 0.305 ppm $(0.003 \sim 0.996 \mathrm{ppm})$ in herbal products sold in Korean drugstores, and $0.007 \mathrm{ppm}(0.002 \sim 0.009 \mathrm{ppm})$ in herbal extracts. Thus, the respective mean daily $\mathrm{Cr}$ intakes were $10.895 \mu \mathrm{g} / \mathrm{d}(0.136 \sim 30.478 \mu \mathrm{g} / \mathrm{d}), 4.927 \mu \mathrm{g} / \mathrm{d}(0.860 \sim$ $11.268 \mu \mathrm{g} / \mathrm{d})$, and $2.019 \mu \mathrm{g} / \mathrm{d}(0.728 \sim 2.766 \mu \mathrm{g} / \mathrm{d})$. A $\mathrm{Cr}$ content higher than $0.7 \mathrm{ppm}$ was observed in six herbal plants and one herbal product sold in Korean drugstores.

Co was detected in all study samples except two herbal products sold in Korean drugstores. The mean Co content was $0.140 \mathrm{ppm}(0.052 \sim 0.413 \mathrm{ppm})$ in herbal plants, $0.057 \mathrm{ppm}$ (up to $0.120 \mathrm{ppm}$ ) in herbal products sold in Korean drugstores, and 0.017 ppm (0.009 0.024 ppm) in herbal extracts. Thus, the respective mean daily Co intakes were $0.970 \mu \mathrm{g} / \mathrm{d}(0.315 \sim 2.739 \mu \mathrm{g} / \mathrm{d}), 1.212 \mu \mathrm{g} / \mathrm{d}$ (up to $4.430 \mu \mathrm{g} / \mathrm{d})$, and $4.998 \mu \mathrm{g} / \mathrm{d}(2.818 \sim 7.130 \mu \mathrm{g} / \mathrm{d})$. Mean daily Co intake greater than $6 \mu \mathrm{g} / \mathrm{d}$ was found from four herbal extracts.

\section{Characteristics according to material (herbal plant) and finished product (herbal product and extract)}

Herbal plants had higher mean metal contents for all metals than those of herbal products and herbal extracts (mean metal contents of herbal plants, Cr 1.543 ppm, Co $0.140 \mathrm{ppm}, \mathrm{Ni} 0.736 \mathrm{ppm}$ ). The lowest mean metal content was detected in herbal extracts (mean metal contents of herbal extracts, Cr 0.007 ppm, Co 0.017 ppm, Ni 0.140 
ppm). However, when this value was converted to mean daily metal intake, Co levels were 5.15 times higher, $\mathrm{Ni}$ levels 8.32 times higher in herbal extract than the herbal plants (mean herbal extracts daily intake Co $4.998 \mu \mathrm{g}, \mathrm{Ni}$ $42.012 \mu \mathrm{g}$; mean herbal plants daily intake Co $0.970 \mu \mathrm{g}$, Ni $5.048 \mu \mathrm{g})$.

\section{DISCUSSION}

As CAM use broadens worldwide, and the international market expands rapidly, emphasis on the safety and quality of herbs and herbal products is increasing ${ }^{17}$. According to the World Health Organization (WHO), herbal products were regulated in 65 countries in 1999 but in as many as 119 in $2012^{18}$.

In Korea, various herbal products are used in medical institutions such as the oriental medicine hospitals, pharmacies, as well as in the private sector in functional foods, teas, and spices. The regulation of heavy metals in herbal products was strengthened in April 2006 in Korea, and the limits of four metals $(\mathrm{Pb} \leq 5 \mathrm{ppm}, \mathrm{As} \leq 3 \mathrm{ppm}, \mathrm{Cd} \leq 0.3$ ppm, and $\mathrm{Hg} \leq 0.2 \mathrm{ppm}$ ) were incorporated into previous regulations recommending total amounts $\leq 30 \mathrm{ppm}$. Because most final herbal extracts and products prescribed by Korean herbal doctors consist of several raw herbal plant materials, herbal extracts and products may have metal levels several times higher than each herbal plant components. In this study, ingesting some herbal extract led to daily metal intake values up to 22.63 times higher Co and up to more than five thousand times higher $\mathrm{Ni}$ than for ingesting an herbal plant (Table 2). However, herbal plants and specific herbal products listed in the KFDA are regulated in Korea, whereas herbal products prescribed by Korean herbal doctors are not. Same regulation limit applies to herbal plants, which are raw materials, and herbal products, the final products. In contrast to the Korean Pharmacopoeia (KP), Canada and USA apply stricter regulations to final products than raw materials ${ }^{19}$. Although the regulations on herbal products have been strengthened, these regulations refer only to certain heavy metals, and there have been no standards for evaluating metals as allergens until now.

Fortunately, most of the herbal plants and products analyzed in this study had little metals relative to permissible tolerable daily intake levels provided by several international organizations (Table 3).

$\mathrm{Ni}$ is a ubiquitous element with strong antigenicity, and $\mathrm{Ni}$ allergies are generally reported in $10 \%$ to $20 \%$ of the population. Food and water are the primary sources of $\mathrm{Ni}$ exposure. The level of dietary $\mathrm{Ni}$ intake varies from 20 to $600 \mu \mathrm{g} / \mathrm{d}$, depending on the geographic area ${ }^{15,20,21}$. A strong correlation has been observed between the amount of ingested $\mathrm{Ni}$ and allergic contact dermatitis. Dietary interventions, including $\mathrm{Ni}$ restriction, are important for treatment and prevention of $\mathrm{Ni}$ allergy, because very low concentrations $(10 \sim 60 \mu \mathrm{g} / \mathrm{kg})$ can elicit allergic reaction after sensitization ${ }^{20,22,23}$. Well-known Ni-rich foods include cocoa, peanuts, and chocolate. Jacob et al. ${ }^{24}$ reported that four Ni allergic children who improved after strict $\mathrm{Ni}$ restriction diet showed abrupt deterioration after eating chocolate bars, and Krecisz et al. ${ }^{14}$ reported a case of systemic contact dermatitis following cocoa ingestion ${ }^{23-25}$. In these two reports, $\mathrm{Ni}$ in the food was approximately $50 \mu \mathrm{g}$ (50 g/chocolate bar, 1.00 [0.85 1.32] mg/kg Ni ${ }^{24} ; 5 \mathrm{~g} /$ recommended daily dose of cocoa powder, $10 \mathrm{mg} / \mathrm{kg} \mathrm{Ni}^{26}$ ). In this study, six herbal extracts had daily $\mathrm{Ni}$ intake similar to or higher than $50 \mu \mathrm{g}$ (Table 2). Han et al. ${ }^{25}$ analyzed $\mathrm{Ni}$ content of Korean foods in 2005 and found considerably more $\mathrm{Ni}$ in most Korean foods than previous reports. For example, the $\mathrm{Ni}$ content of Korean green tea bags is 7,852 times higher than that reported by Veien and Andersen $^{26}$ in $1986^{25}$. Fortunately, the $\mathrm{Ni}$ contents of herbal plants and products in this study were considerably lower than those previous reported from other countries ${ }^{2,3,27-31}$. However, the metal contents of herbal plants and products can differ greatly, even in the same country, depending on types of selected herbal plants, cultivation environment, and time obtained ${ }^{2,29}$. Thus, interpretations

Table 3. Permissible tolerable daily intake (PTDI)

\begin{tabular}{|c|c|}
\hline Metal & PTDI \\
\hline Chromium $(\mathrm{Cr})$ & $\begin{array}{l}\text { not evaluated (JECFA), } 0.15 \mathrm{mg} \mathrm{Cr}(\mathrm{III}) / \mathrm{kg} / \mathrm{d} \text { (UK EVM), } 0.9 \mu \mathrm{g} \mathrm{Cr}(\mathrm{IV}) / \mathrm{kg} / \mathrm{d}(\mathrm{WHO} / \mathrm{IPCS}), 300 \mu \mathrm{g} \mathrm{Cr} / \mathrm{kg} / \mathrm{d}(\mathrm{VKM}) \text {, } \\
250 \mu \mathrm{g} \mathrm{Cr} / \mathrm{d} \text { (WHO/IPCS) }\end{array}$ \\
\hline Cobalt $(\mathrm{Co})$ & 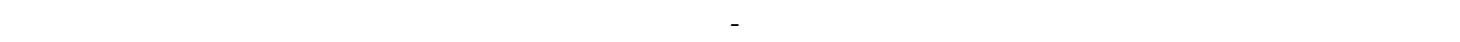 \\
\hline Nickel (Ni) & $6.0 \mu \mathrm{g} \mathrm{Ni} / \mathrm{kg} / \mathrm{d}($ US EPA), $5 \mu \mathrm{g} \mathrm{Ni} / \mathrm{kg} / \mathrm{d}(\mathrm{FAO} / \mathrm{WHO})$ \\
\hline
\end{tabular}

JECFA: Joint Food and Agriculture Organization/World Health Organization Expert Committee on Food Additives, UK EVM: United Kingdom Expert Group on Vitamins and Minerals, WHO: World Health Organization, IPCS: International programme on chemical safety, VKM: Norwegian Scientific Committee for Food and Environment, US EPA: United States Environmental Protection Agency, FAO: Food and Agriculture Organization. 
of these results should be careful ${ }^{2,3,27-31}$.

$\mathrm{Cr}$ is commonly used in alloys and showed sensitization rate up to $6 \%{ }^{32}$. Irritant dermatitis, dyshidrotic eczema, and contact dermatitis are closely related to dietary or medicinal Cr. Fregert and Rorsman ${ }^{33}$ reported that a provocation test using $50 \mu \mathrm{g}$ oral dichromate salt in five $\mathrm{Cr}$ allergy patients caused acute flare-ups of hand eczema. Korean herbal products contain average $\mathrm{Cr}$ of $0.618 \mathrm{ppm}$, which is six times higher than daily diet $(0.1 \mathrm{ppm})^{34}$. In this study, six herbal plants and one herbal product contained five times more $\mathrm{Cr}$ than nuts $(0.7 \mathrm{ppm})$, a wellknown Cr-rich food ${ }^{35}$. One herbal plants, Herb G (prepared Rehmannia root) contained 3.685 ppm (Table 2).

Co exposure commonly occurs via inhalation, oral ingestion, and contact and can cause irritant dermatitis, contact dermatitis, allergic vasculitis, and hand eczema (dyshidrotic eczema $)^{36}$. Like $\mathrm{Ni}$, geographic and environmental conditions affect Co contents of food and water ${ }^{37}$. Stuckert and Nedorost ${ }^{36}$ suggested that $<12 \mu \mathrm{g} / \mathrm{d}$ is appropriate for standard Co-restricted diet. In this study, four herbal extracts had Co levels higher than $50 \%$ of the restricted diet standard, and one (Herbal extract G, $7.13 \mu \mathrm{g} / \mathrm{d}$ ) had up to $60 \%$ (Table 2).

In Korea, many patients use CAMs to treat allergic diseases such as asthma, rhinitis, atopic dermatitis, and urticaria ${ }^{1}$. But significant levels of high-antigenicity metals, such as $\mathrm{Ni}, \mathrm{Co}$ and $\mathrm{Cr}$ are contained in Korean herbal plants and products compared with the metal levels in $\mathrm{Ni}$ or Cr-rich foods which can aggravate metal allergy patient or those of Co-restricted diets.

In addition to the metals assessed in this study, other studies have reported that CAMs contain manganese, iron, zinc, and selenium. Assessments of these metals in Korean herbal products should be conducted in the future ${ }^{4,30}$.

When describing metal-restricted diets, most authors distinguish between metal-rich and low-metal foods based only on metal content. However, in addition to content, actual dietary intake amount is an important factor for metal exposure. Dietary intake should be taken into consideration in dietary education. In this study, the lowest mean metal content was detected in herbal extracts compared with herbal plants and products sold in Korean drugstores. However, when the contents were converted to daily intake values, there was 5.15 times higher in Co and 8.32 times higher in $\mathrm{Ni}$ daily metal intake from herbal extracts than from herbal plants.

The present study is limited in that it involved a small sample number and purchased only in Seoul. Furthermore, because all of the samples were KFDA-approved, these results do not represent the herbs obtained from markets. In previous analyses of Korean herbs, only certain heavy metals ( $\mathrm{Pb}, \mathrm{As}, \mathrm{Cd}$, and $\mathrm{Hg}$ ) in raw herbal plant were assessed. Therefore, this study was the first to analyze metal antigens in Korean herbal plants and the final ingested forms of herbal products. The herbal preparations contained similar or higher metal than known metal-rich foods. The KFDA has strict regulations on heavy metals, pesticide, and aflatoxins but does not provide standards for metal antigens. The allergenicities of herbal products have been underestimated. Metal exposure differs depending on the intake amount, and place of purchase, even for the same herb. Therefore, doctors should perform a detailed medical history about the usage of herbal products and the place of purchase for patients with intractable contact dermatitis or acute deteriorated lesions.

\section{CONFLICTS OF INTEREST}

The authors have nothing to disclose.

\section{ORCID}

Min Jung Choi, https://orcid.org/0000-0002-4973-4254

Ji Yeon Byun, https://orcid.org/0000-0003-4519-9474

Hae Young Choi, https://orcid.org/0000-0003-3460-2539

You Won Choi, https://orcid.org/0000-0001-6315-3889

\section{REFERENCES}

1. Lim DO, Jung MJ, Park JS, Seo KS, Hwang JW, Kim EY, et al. Investigation of herbal medicine use and herbal medicine consumption situation in Korea. Cheongju: Korea Health Industry Development Institute; 2014. Report No.: 11-1352 0000-000547-12. 806 p.

2. Obi E, Akunyili DN, Ekpo B, Orisakwe OE. Heavy metal hazards of Nigerian herbal remedies. Sci Total Environ 2006;369:35-41.

3. Wong MK, Tan P, Wee YC. Heavy metals in some Chinese herbal plants. Biol Trace Elem Res 1993;36:135-142.

4. Khan IA, Allgood J, Walker LA, Abourashed EA, Schlenk D, Benson $\mathrm{WH}$. Determination of heavy metals and pesticides in ginseng products. J AOAC Int 2001;84:936-939.

5. Vaikosen EN, Alade GO. Evaluation of pharmacognostical parameters and heavy metals in some locally manufactured herbal drugs. J Chem Pharm Res 2011;3:88-97.

6. Pharmaceutical Affairs Law Act of 2017 Dec 23 (KR), Pub. L. No. 13598, Article. 51 (Mar. 23, 2013). Korean.

7. Pharmaceutical Affairs Law Act of 2017 Dec 23 (KR), Pub. L. No. 13598, Article. 52 (Mar. 23, 2013). Korean.

8. Herbal Medicine Safety and Quality Control Regulation Act of 2016 Mar 30 (KR), Pub. L. No. 2016-21 (Mar. 30, 2016). Korean.

9. Food Sanitation Act of 2018 Jun 20 (KR), Pub. L. No. 15277, Article 7 (Dec. 19, 2017). Korean.

10. Kim KS, Cho HJ, Lee $\mathrm{CH}$, Ahn KJ, Kang DG. A case of 
contact dermatitis due to herb ointment. Korean J Dermatol 1990;28:212-215.

11. de Medeiros LM, Fransway AF, Taylor JS, Wyman M, Janes J, Fowler JF Jr, et al. Complementary and alternative remedies: an additional source of potential systemic nickel exposure. Contact Dermatitis 2008;58:97-100.

12. van Ulsen J, Stolz E, van Joost T. Chromate dermatitis from a homeopathic drug. Contact Dermatitis 1988;18:56-57.

13. Audicana M, Bernedo N, Gonzalez I, Muñoz D, Fernández E, Gastaminza G. An unusual case of baboon syndrome due to mercury present in a homeopathic medicine. Contact Dermatitis 2001;45:185.

14. Krecisz B, Chomiczewska D, Kiec-Swierczynska M, Kaszuba A. Systemic contact dermatitis to nickel present in cocoa in 14-year-old boy. Pediatr Dermatol 2011;28:335-336.

15. Rietschel RL, Fowler JF, Fisher AA. Fisher's contact dermatitis. 6th ed. Hamilton: BC Decker Inc, 2008:651652, 663-664, 668-669, 671-680.

16. Choi WS, Koo SW, Cho JH, Kim HJ, Lim YJ; the Nielsen company Korea, Seoul, KR. Daily dose study for herbal medicine- final report. Cheongju: the Ministry of Food and Drug Safety; 2016 Nov. Report No.: 15172-194. 242 p.

17. Jung JY; Korea Institute of Science and Technology, Daejeon, KR. The study of hazard materials monitoring and their intaking rate on oriental herbal medicine: heavy metal, pesticide and sulfur dioxide-final report. Cheongju: the Ministry of Food and Drug Safety; 2006 Nov. Report No.: 06082-201. $496 \mathrm{p}$.

18. Qi Z. WHO Traditional Medicine Strategy 2014-2023. Geneva, Switzerland: World Health Organization Press, 2013. 78 p.

19. Kim JS, Lee KY, Cho LK, Yee NH, Jang MH, Park SH, et al; Korea Institute for Health and Social Affairs, Sejong, KR. Risk assessment of hazardous substances requiring management in oriental (herbal) medicine-final report. Seoul: Supported by the Ministry of Food and Drug Safety; 2015 Nov. Report No.: 15172-195. 376 p.

20. Jensen CS, Menné T, Johansen JD. Systemic contact dermatitis after oral exposure to nickel: a review with a modified meta-analysis. Contact Dermatitis 2006;54:79-86.

21. Sharma AD. Low nickel diet in dermatology. Indian J Dermatol 2013;58:240.

22. Kaaber K, Veien NK, Tjell JC. Low nickel diet in the treatment of patients with chronic nickel dermatitis. Br J Der- matol 1978;98:197-201.

23. Antico A, Soana R. Nickel sensitization and dietary nickel are a substantial cause of symptoms provocation in patients with chronic allergic-like dermatitis syndromes. Allergy Rhinol (Providence) 2015;6:56-63.

24. Jacob SE, Hamann D, Goldenberg A, Connelly EA. Easter egg hunt dermatitis: systemic allergic contact dermatitis associated with chocolate ingestion. Pediatr Dermatol 2015;32:231-233.

25. Han $\mathrm{HJ}$, Lee $\mathrm{BH}$, Park $\mathrm{CW}$, Lee $\mathrm{CH}$, Kang YS. A study of nickel content in Korean foods. Korean J Dermatol 2005; 43:593-598.

26. Veien NK, Andersen MR. Nickel in Danish food. Acta Derm Venereol 1986;66:502-509.

27. Milani RF, Morgano MA, Saron ES, da Silva FF, Cadore S. Evaluation of direct analysis for trace elements in tea and herbal beverages by ICP-MS. J Braz Chem Soc 2015;26: 1211-1217.

28. Mohammed AL, Hammud KK, Zamil SK. Macro- and trace metals in three medicinal herbs collected from Baghdad, Iraq market. Int J Pharm Sci 2014;5:799-802.

29. Ekeanyanwu C, Njoku JO, Nwodu PO, Njokuobi AE. Analysis of some selected toxic heavy metals in some branded Nigerian herbal products. J Appl Pharm Sci 2013;3:88-91.

30. Soylak M, Cihan Z, Yilmaz E. Evaluation of trace element contents of some herbal plants and spices retailed in Kayseri, Turkey. Environ Monit Assess 2012;184:3455-3461.

31. Naithani V, Kakkar P. Evaluation of heavy metals in Indian herbal teas. Bull Environ Contam Toxicol 2005;75:197-203.

32. Sharma AD. Low chromate diet in dermatology. Indian J Dermatol 2009;54:293-295.

33. Fregert $S$, Rorsman $H$. Allergic reactions to trivalent chromium compounds. Arch Dermatol 1966;93:711-713.

34. Burrows D. Chromium and the skin. Br J Dermatol 1978;99: 587-595.

35. Ysart G, Miller P, Crews H, Robb P, Baxter M, De L'Argy C, et al. Dietary exposure estimates of 30 elements from the UK Total Diet Study. Food Addit Contam 1999;16:391-403.

36. Stuckert J, Nedorost S. Low-cobalt diet for dyshidrotic eczema patients. Contact Dermatitis 2008;59:361-365.

37. Hokin B, Adams M, Ashton J, Louie H. Analysis of the cobalt content in Australian foods. Asia Pac J Clin Nutr 2004;13:284-288. 